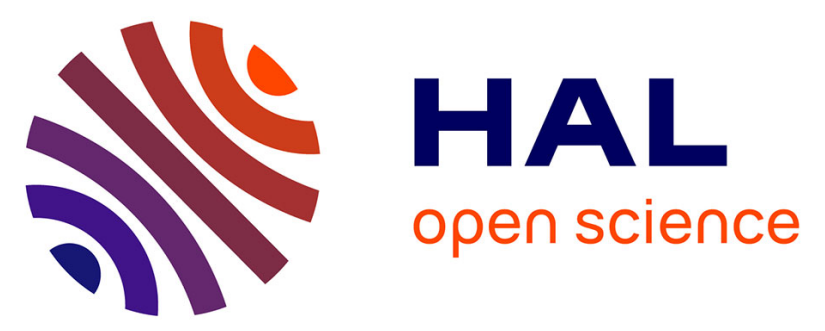

\title{
An efficient and rapid method for the enumeration of heterotrophic prokaryotes in coastal sediments by flow cytometry
}

Céline Lavergne, Laureen Beaugeard, Christine Dupuy, Courties Claude, Agogué Hélène

\section{To cite this version:}

Céline Lavergne, Laureen Beaugeard, Christine Dupuy, Courties Claude, Agogué Hélène. An efficient and rapid method for the enumeration of heterotrophic prokaryotes in coastal sediments by flow cytometry. Journal of Microbiological Methods, 2014, 105, http://www.journals.elsevier.com/journalof-microbiological-methods/. 10.1016/j.mimet.2014.07.002 . hal-01086641

\section{HAL Id: hal-01086641 https://hal.science/hal-01086641}

Submitted on 24 Nov 2014

HAL is a multi-disciplinary open access archive for the deposit and dissemination of scientific research documents, whether they are published or not. The documents may come from teaching and research institutions in France or abroad, or from public or private research centers.
L'archive ouverte pluridisciplinaire HAL, est destinée au dépôt et à la diffusion de documents scientifiques de niveau recherche, publiés ou non, émanant des établissements d'enseignement et de recherche français ou étrangers, des laboratoires publics ou privés. 


\section{An efficient and rapid method for the enumeration of 2 heterotrophic prokaryotes in coastal sediments by flow 3 cytometry}

4

5 Lavergne Céline ${ }^{1}$, Beaugeard Laureen ${ }^{1}$, Dupuy Christine ${ }^{1}$, Courties Claude $^{2}$, Agogué Hélène $^{1}$ 6

$7 \quad{ }^{1}$ LIENSs, UMR 7266 Université de La Rochelle - CNRS, 2 rue Olympe de Gouges, 17000 8 La Rochelle, France

$9{ }^{2}$ Sorbonne Universités, UPMC Univ Paris 06, UMS 2348, Laboratoire d'Océanographie 10 Microbienne, Observatoire Océanologique, F-66650 Banyuls/Mer, France

12 Corresponding author: Lavergne Céline LIENSs, UMR 7266 Université de La Rochelle 13 CNRS, 2 rue Olympe de Gouges, 17000 La Rochelle, France.

$14 \quad$ Tel : $+33(0) 546507644$

$15 \quad$ Fax : +33(0)5 46507663

16 E-Mail : celine.lavergne@ univ-lr.fr

18 Running title: FCM for counting benthic prokaryotes 


\section{Abstract}

Flow cytometry offers an easy and powerful way to assess multi-parametric data in different domains, notably in the environmental sciences. Because evaluating heterotrophic prokaryotic abundance is crucial to understand an ecosystem's functioning, we propose a quick and efficient protocol for 1) cell's detachment in muddy coastal sediments followed by 2) enumeration of prokaryotes by flow cytometry compared to epifluorescence microscopy and 3) a type of storage adapted for benthic samples. First, samples preparation by incubation in a detergent mix containing sodium pyrophosphate (0.01 M final concentration) and Tween 80 (0.1\% final concentration) drastically increased cell detachment from sediment particles (+130.40\%) compared to extraction with sodium pyrophosphate only. Cell sorting allowed to control the efficiency of the extraction as few cells were found attached to sediment particles in epifluorescence microscopy after sorting. Flow cytometry gave consistent results with strong reliability by counting 1.81 times more cells compared to epifluorescence microscopy. Thirdly, results revealed that sediment samples fixed with formaldehyde and then liquid- $\mathrm{N}_{2}$ frozen and directly stored at $-80^{\circ} \mathrm{C}$ can be analysed within 3 months. In routine, our method of extraction and counting allowed to evaluate $83.67 \%$ of the real abundance in a sediment sample. Finally, this optimized technique was applied on sandy and muddy coastal and freshwater sediments and allowed us to prove the high efficiency of this new method. Flow cytometry is a fast, replicable and low-cost method for counting heterotrophic prokaryotes, even for sediment samples. The two-step method that we developed enables high frequency analyses (30 samples in less than 4 hours).

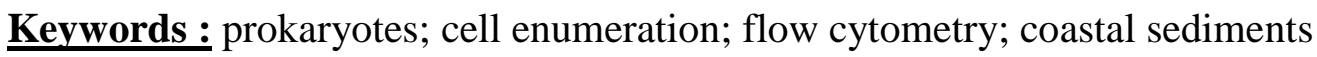




\section{Introduction}

Microorganisms dominate marine ecosystems (DeLong et al., 2006) and were often considered as a "Black Box" by scientists (Fuhrman et al., 2002). To investigate this "Black Box", many studies have focused on new technologies and advances in molecular biology methods, allowing researchers to acquire a huge quantity of phylogenetic and potential physiologic information from oceans and marine coastal ecosystems. But these revolutionary "omics" data need to be completed by single-cell analysis, metabolic studies, and basic determination of prokaryotic abundances. Prokaryotes (Bacteria and Archaea) are key organisms in biogeochemical cycles in all marine environments (Azam and Malfatti, 2007, DeLong, 2009) and the first step to study these communities is to estimate their abundance within the microbial assemblage. Estimations of abundance showed that prokaryotes are as abundant as $10^{6}$ cells. $\mathrm{mL}^{-1}$ in ocean water (Whitman et al., 1998) and more than $10^{8}$ cells.mL

${ }^{1}$ in marine surface sediments (Jorgensen and Boetius, 2007). In sediments, prokaryotes play a crucial role in the food web as they remineralize organic matter and lead major cycles such as nitrogen and carbon cycles. Most specifically, heterotrophic prokaryotes are a majority throughout the whole sediment depth and can be present until almost $2 \mathrm{~km}$ below the surface (Ciobanu et al., 2014).

The first advances in heterotrophic prokaryotic enumeration were made using epifluorescence microscopy (EFM) (Porter and Feig, 1980). Fluorochromes combined with EFM have been used to develop standardized methods to successfully count bacteria in freshwater and marine water columns (Daley, 1979). The most widespread way of staining cells is to target DNA with a fluorescent dye such as DAPI (4', 6-diamidino-2-phenylindole), currently used in microscopy (Porter and Feig, 1980). Montagna (1982) showed under Acridine Orange (AO)-EFM observation that bacteria in muddy sediments occur at levels two orders of magnitude greater than in sandy sediments. Nowadays, EFM is still the most 
widespread technique for estimating the abundance of prokaryotes (see Supplementary Information Table 1 for references). Nevertheless, Robertson and Button (1989) were the first to use flow cytometry (FCM) to enumerate heterotrophic prokaryotic cells by DAPI-staining in marine and freshwater samples. Even if FCM seemed to be an accurate and rapid method for determining heterotrophic prokaryotic cells, advances were needed in storage conditions or fixative effects on benthic samples. These fixatives were known to permeate cells (Troussellier et al., 1995); consequently, the interactions between dyes and fixatives needed to be taken into account when choosing dyes. During the exponential phase of FCM utilization for environmental marine samples, many dyes have been reported in the literature such as DAPI, Hoechst 33342, TO-PRO-1, SYBRGreen (I or II), SYTO13 etc... (details are reviewed in Gasol and Del Giorgio (2000)). With technological advances, FCM became more and more useful in marine microbiology and offered new challenges to scientists, such as the prokaryotic enumeration in soils and sediments and the use of specific probes (Fluorescence in situ hybridization - FISH) (Llobet-Brossa et al., 1998). For sediment and soil analysis, the dye mostly used to stain DNA is SYBRGreen I (Kallmeyer et al., 2008), and many authors fixed cells with formaldehyde (Epstein and Rossel, 1995) preferentially, but the best temperature for long time storage is still unclear.

FCM is now widely used for water column samples, but sediment samples carry the difficulties of a solid matrix rich in detritus, minerals and exopolymeric substances (EPS). Indeed, sediments are particularly hard to study because dyes (e.g. AO or DAPI) can produce a high fluorescence background with clay and silt-rich sediments containing a high quantity of detritus and EPS (Kuwae and Hosokawa, 1999). Additionally, in such environments, prokaryotic cells are often attached to sediment particles by EPS (Decho, 2000), creating a complex with organic and mineral particles (Epstein and Rossel, 1995, Kallmeyer, et al., 2008). The point of divergence between microbiologists remains the separation method to 
detach cells from the solid matrix. In order to improve counting yield in sediment, chemical dispersion and physical detachment should be applied. Physical detachment can be achieved by isoelectric method (Jaspers and Overmann, 1997), capillary electrophoresis (Schneiderheinze et al., 2000), sonication bath (Duhamel and Jacquet, 2006, Ellery and Schleyer, 1984, Gasol, 1993), or probes (Albright et al., 1986, Epstein and Rossel, 1995, Kallmeyer, et al., 2008), vortexing (Frischer et al., 2000, Whiteley et al., 2003), or by blender homogenization (Lindahl and Bakken, 1995, Maron et al., 2006, Yamamoto and Lopez, 1985). The sonication probes appear to be the best way to mechanically detach prokaryotic cells from sediment particles, and applying it with an intensity of $60 \mathrm{~W}$ for 30 seconds has been shown to be a good compromise between high counting yield and avoiding lysing cells (Garet, 1996, Lei et al., 2010). Concerning the chemical dispersion solution, the most cited is the sodium pyrophosphate ( $\mathrm{NaPp}$ ), which is often found in detergent solutions in combination with Tween 20 (Amalfitano and Puddu, 2009) or Tween 80 (Duhamel and Jacquet, 2006, Epstein and Rossel, 1995), the phosphate buffer saline (PBS) solution (Barra Caracciolo et al., 2005), the sodium chloride (Fazi et al., 2005), or methanol (Kallmeyer, et al., 2008, Lunau et al., 2005). Moreover, it is possible to apply a density gradient (Kallmeyer, et al., 2008, Morono et al., 2013) after the chemical separation in order to improve the time and reliability of the counting (Fazi, et al., 2005). However, in the literature, it remains unclear which best dilution and detergent mix need to be applied to sediment samples in order to detach the maximum of aggregates and cells adsorbed on particles.

Nowadays, no simple and standardize method existed to study microorganisms in different type of sediments. On that basis, this study aims at optimizing sediments fixation and storage, cells separation and comparing two analysis methods (EFM and FCM) to count benthic heterotrophic prokaryotes. 


\section{Materials and Procedures}

117

\subsection{Sample collection, fixation and storage}

Muddy sediments from the French Atlantic coast were sampled in the Moëze Bay and the Aiguillon Bay from the surface to $10 \mathrm{~cm}$-deep. The sediment samples were collected in 2012 and 2013 at low tide using cores (15 cm diameter). Back in the laboratory (less than one hour), the sediments were homogenized, and sub-samples were put in containers using sterile $50 \mathrm{~mL}$ syringes with cutoff tips. Finally, subsamples were fixed with $0.2 \mu \mathrm{m}$-filtered formaldehyde solution (vol/vol, 2\% final concentration) and kept according two conditions: at $+4^{\circ} \mathrm{C}$ in the dark or frozen in liquid- $\mathrm{N}_{2}$ directly followed by storage at $-80^{\circ} \mathrm{C}$. Different storage times were tested on five different muddy samples in duplicates: 1 week, 1 month, 3 months, and 6 months after sampling.

\subsection{Protocol development}

Here, we described the proceedings of the protocol development. Different steps of the procedure were investigated in order to improve the enumeration of prokaryotes in sediment: 1) sample preparation before mechanical extraction; 2) utility of centrifugation to remove sediment particles; 3 ) repetitive steps of extraction to improve cell counting yield.

\subsubsection{Sample preparation before mechanical extraction}

First tests were achieved by preparing sediment slurries with a solution of $\mathrm{NaPp} 0.01 \mathrm{M}$ (Pascal et al., 2009, Tso and Taghon, 1997). Then, in order to disaggregate the attached cells, Tween 80 (0.1\% final concentration) was added to the NaPp solution $(0.01 \mathrm{M})$. Indeed, Tween 80 is a non-ionic surfactant known to decrease particle aggregates and to enhance detachment of cells from particles in sediment samples (Velji and Albright, 1986, Yoon and Rosson, 1990). The influence of Tween 80 addition on the cell recovery efficiency was 
139 evaluated on 55 samples. According to preliminary tests, using NaPp solution or

$140 \mathrm{NaPp}+\mathrm{Tween} 80$ mixture, slurries were prepared by processing to successive dilutions until $141 \quad 1: 2,000(1: 10 ; 1: 100 ; 1: 500 ; 1: 1,000$ and $1: 2,000)$ to reduce sediment background (dos Santos

142 Furtado and Casper, 2000, Duhamel and Jacquet, 2006). A vortexing step of 5 sec was applied

143 before and after each successive dilution.

144 According to Epstein and Rossel (1995) and Velji and Albright (1986)

145 recommendations, 30 minutes of incubation at $+4^{\circ} \mathrm{C}$ was used to detach cells from sediment

146 particles. Then, mechanical extraction consisted of sonicating samples $30 \mathrm{~s}$ at $60 \mathrm{~W}$ in ice with

147 a sonicator probe (Branson, SLPE-150, 1/8" or $3 \mathrm{~mm}$ microtip, 40KHz) (Lei, et al., 2010).

\section{$148 \quad 2.2 .2 \quad$ Utility of centrifugation to remove sediment particles}

149 The impact of a centrifugation step was tested by applying or not a low speed centrifugation.

150 A first part of extracted samples was centrifuged at $1000 \mathrm{~g}$ at $+4^{\circ} \mathrm{C}$ during $1 \mathrm{~min}$, after which

151 supernatant was transferred and then stained for EFM and FCM analysis (see below for

152 staining settings). On the second part of extracted samples, a proportion was mixed,

153 transferred and then stained for EFM and FCM analysis and centrifugation was applied on the

154 remaining proportion to collect sediment and attached cells for a second extraction step.

155 In any case, after centrifugation step, the remaining supernatant was discarded and the 156 pellet was re-suspended in the detergent mix [0.01 M NaPp and Tween $80(0.1 \%$ final conc.)]

157 with the same volume of supernatant. By this way, the cells remaining attached to the

158 sediment particles in the pellet can be detached and counted in a second step.

\section{$159 \quad 2.2 .3 \quad$ Repetitive steps of extraction to improve cell counting}

160 Because cells can be still attached to sediment particles even after the first extraction, we 161 evaluated the number of repetitive extraction steps needed to improve cell counting yield. The 162 second step was processed as the first one, by incubating the samples in the detergent mix 
163 [0.01 M NaPp and Tween 80 (0.1\% final conc.)] for $30 \mathrm{~min}$ at $+4^{\circ} \mathrm{C}$. Then, sonication was

164 repeated (same settings as above) before the analysis.

Aiming at evaluating how many steps were needed, extraction process was repeated

166 until cells recovery reaches a plateau on 15 different samples. Thus, the total prokaryotic cell

167 abundance corresponded to the sum of all the counting values obtained in each extraction 168 step.

\subsection{Microscopic count}

Extracted samples were stained with 4',6-diamidino-2-phenylindole (DAPI, 250 $\left.\mu \mathrm{g} \cdot \mathrm{ml}^{-1}, 15 \mathrm{~min},+4^{\circ} \mathrm{C}\right)$ and filtered through black polycarbonate membrane $(0.2 \mu \mathrm{m}$ pore size,

$17225 \mathrm{~mm}$, Nucleopore) (Porter and Feig, 1980). Next, filters were mounted on slides using anti-

173 fading oil type $\mathrm{F}$ (Olympus, Japan), and conserved at $-20^{\circ} \mathrm{C}$ until counting. Finally, counts

174 were made with an epifluorescence microscope (Axioskop2, Carl Zeiss Microscopy, LLC, 175 United-States) at 1,000 x magnification under UV excitation (Filter set 01, $397 \mathrm{~nm}$ - Zeiss).

176 For each sample, a minimum of 20 fields (> 600 cells) were counted and averaged (Lebaron 177 et al., 1994).

\subsection{Flow cytometric and cell sorting analysis}

For each extraction step, the flow cytometric analysis consisted of SYBRGreen Istained (1:10,000 final concentration) extracted sample during $15 \mathrm{~min}$ in the dark at room

181 temperature. Fluorescent beads (Fluoresbrite Multi fluorescent microsphere $1.0 \mu \mathrm{m}$, 182 Polysciences, Germany) were added simultaneously to each sample in order to analyze cell

183 fluorescence and scatter properties of samples. Each sample was analyzed for $30 \mathrm{~s}$ at low flow 184 speed with FacsCanto II cytometer (3-laser, 8-color (4-2-2), BD Biosciences) equipped with a 185 20-mW 488-nm coherent sapphire solid state blue laser. Data were acquired using DIVA 186 software provided by BD-Biosciences. 
A cell sorter (FACSAria BF-Biosciences) was used to control extraction yield on

188 prokaryotic population. Then, sorted fraction were observed using EFM (BX300, Olympus)

189 to take pictures.

190 Stained cells were discriminated according to green fluorescence (FL1) from

191 SYBRGreen staining and side scatter properties (SSC). Picophytoplanktonic cells are also

192 discriminated based on their red fluorescence (FL3) and SSC properties and excluded from

193 final prokaryotic counts measured on a gate SSC-FL1 (Marie et al., 2001).

194 Accurate cell concentrations were performed using TruCount beads from BD-

195 Biosciences (excitation: red laser 633 nm; emission: FL5 660/20 nm).

$196 \quad 2.5 \quad$ Statistical analysis

197 All statistical analysis was performed using $\mathrm{R}$ software ( $\mathrm{R}$ core Team, 2013). The

198 effect of the addition of Tween 80 was tested with a Paired t-test. The influence of the

199 parameters tested or percentage of sand in samples was evaluated by applying a Kruskal-

200 Wallis rank sum test for one sample and Wilcoxon test for two paired samples on cell 201 abundance values. The relationship between FCM and EFM was shown by fitting a 202 significant linear regression. Effects of storage conditions were tested with a 2-way analysis 203 of variance (ANOVA), residuals were tested for application validation and a TukeyHSD post204 hoc test was used. 


\section{Results}

206 Hereby, we described the results of the protocol development proceedings and then the final 207 protocol that we succeed to establish.

\subsection{Sample preparation}

First, slurries were prepared with NaPp $0.01 \mathrm{M}$ alone and cell sorting flow cytometry

followed by EFM observations were used to visualize the extracted populations. Two

211 populations were observed: free prokaryotic cells population and attached-prokaryotic cells

212 population. The NaPp alone at $0.01 \mathrm{M}$ was apparently not efficient enough to separate cells

213 from sediment particles, because attached prokaryotic cells were still present in the samples 214 and represented $27.7 \%$ of the total abundance. On this basis, the effect of adding Tween 80 215 was evaluated to minimize cell aggregation (Yoon and Rosson, 1990). Both FCM and EFM 216 counting revealed a higher cell counting yield (Fig. 1), with an increase of $130.40 \% \pm 12.49$ 217 SE and $176.79 \% \pm 14.25$ SE respectively, compared to the treatment without Tween 80 . 218 Adding Tween 80 to NaPp in the mixture significantly improve the number of cells counted in 219 FCM (Paired t-test: $\mathrm{t}=-9.6127, \mathrm{df}=54, p$-value <0.001) and EFM (Paired $\mathrm{t}$-test: $\mathrm{t}=-$ $22027.1056, \mathrm{df}=35, p$-value $<0.001)$. After two repetitive steps, cell recovery efficiency rose 221 from $43.3 \% \pm 2.0 \mathrm{SE}$ without Tween to $92.5 \% \pm 2.0 \mathrm{SE}$ with addition of Tween 80 . 222 Moreover, microscopic analysis on sorted populations confirmed that the counted cells were 223 free cells, clearly separated from sediment particles when Tween 80 was added to the mixture. 224 Consequently, it appears that Tween 80 disaggregated efficiently benthic cells and therefore 225 improved the cell counting results (Fig. 1). The recommended protocol is thus to use sodium 226 pyrophosphate $(\mathrm{NaPp})$ and Tween 80 treatment to prepare sediment samples for heterotrophic 227 prokaryotes enumeration by FCM (Fig. 5). 


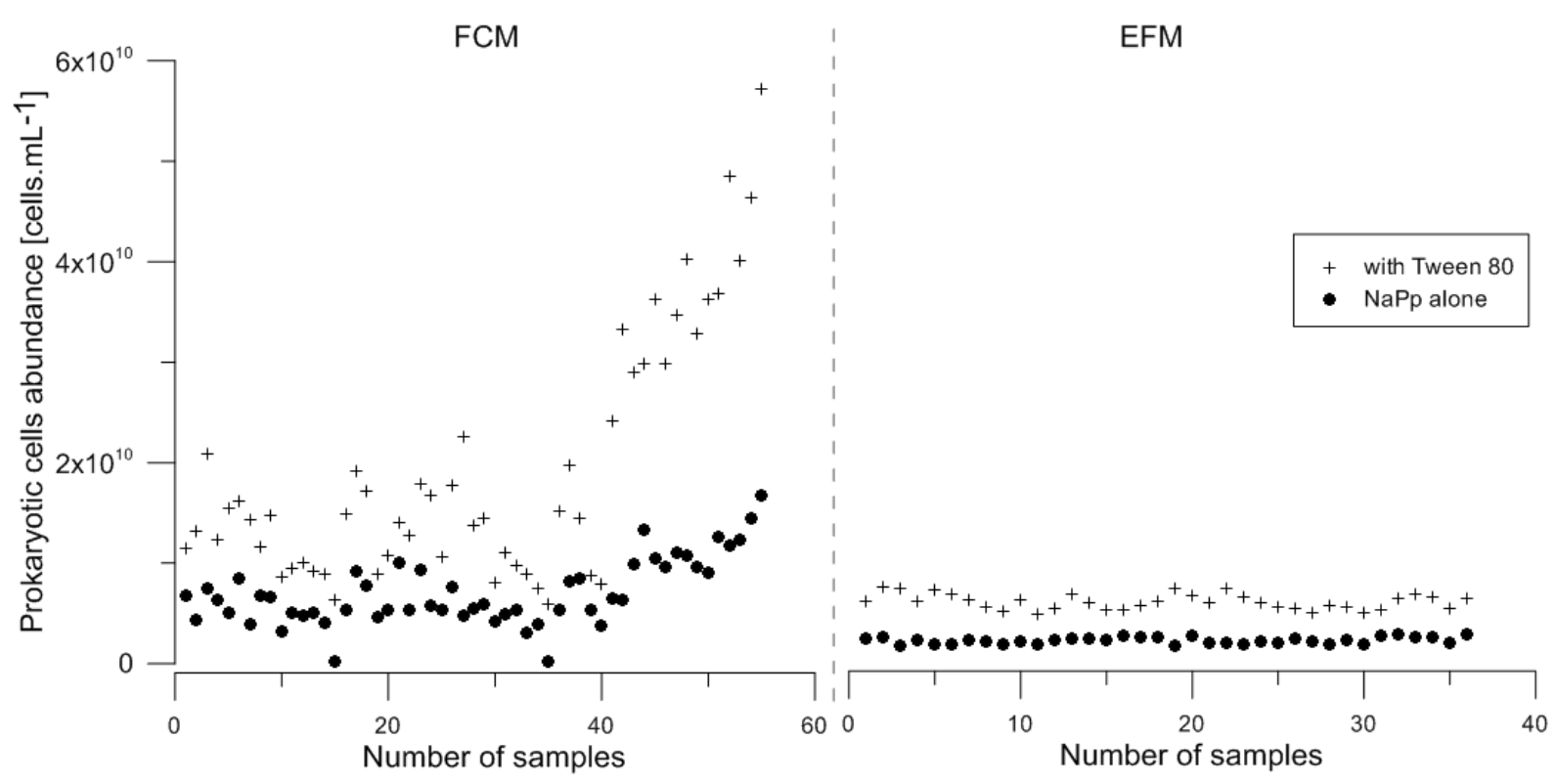

230 Fig. 1. Effects of the addition of Tween 80 to sodium pyrophosphate $(\mathrm{NaPp})$ on prokaryotic

231 cell abundance in sediment samples (FCM counts from SYBRGreen: $n=55$; EFM counts

232 from DAPI: $\mathrm{n}=36$ ). Values for all the samples tested are presented. Crosses represented

233 samples extracted with Tween 80 and $\mathrm{NaPp}$, and circles represented samples extracted with 234 NaPp alone. 


\subsection{Utility of centrifugation}

The utility of a centrifugation step before counting analysis was tested by performing an experiment with and without low speed centrifugation $\left(1,000 \mathrm{~g}, 1 \mathrm{~min},+4^{\circ} \mathrm{C}\right)$. Experiments showed that centrifugation moderately decreased cell counts $(-1.71 \%)$ in FCM and EFM because cells that remained attached to the particles were removed (data not shown). Settling velocities of sands have been calculated according to Soulsby (1997), and we evaluated that the settling time of particles is inferior to the standing step applying on cytometer to acquire data before recording. Indeed, particles of $62 \mu \mathrm{m}$ will take 4.8 seconds to settle in the tube and the cytometer takes 5 seconds to acquire and 10 seconds to record. The particles cannot collapse the flow cell chamber. Thus, we proposed to analyse samples without the centrifugation step and then to centrifuge samples afterward to proceed to a second cells extraction on the pellet.

\subsection{Repetitive steps of extraction}

After the first extraction, $57.04 \% \pm 2.58 \mathrm{SE}$ of cells were extracted and counted. The cumulative cell recovery increased strongly and reached a plateau after the fourth extraction (Fig. 3), showing that in routine analysis it will not be necessary to do more than four extractions. The coefficient of variation of the first extraction was the highest, reaching 17.52 \%. The strongest decrease in $\mathrm{CV}$ was observed between the first and the second extraction (Fig. 2) showing that the second extraction allowed counting a higher number of cells $(83.67 \% \pm 0.94 \mathrm{SE})$ with a lower imprecision $(\mathrm{CV}<5 \%)$. After that, the $\mathrm{CV}$ continued to decrease with lower range values. Doing eight extractions can be time consuming and expensive. In our case, with sediment samples, eight extractions were not necessary. Thus, for routine analysis of benthic samples by FCM, we propose a 2-step extraction as a good compromise among 1$)$ cell recovery efficiency $(83.67 \% \pm 0.94 \mathrm{SE})$ and accuracy $(\mathrm{CV}=4.34)$; and 2) analysis time (4 hours for 30 samples) and cost. 
Counting method of benthic prokaryotes

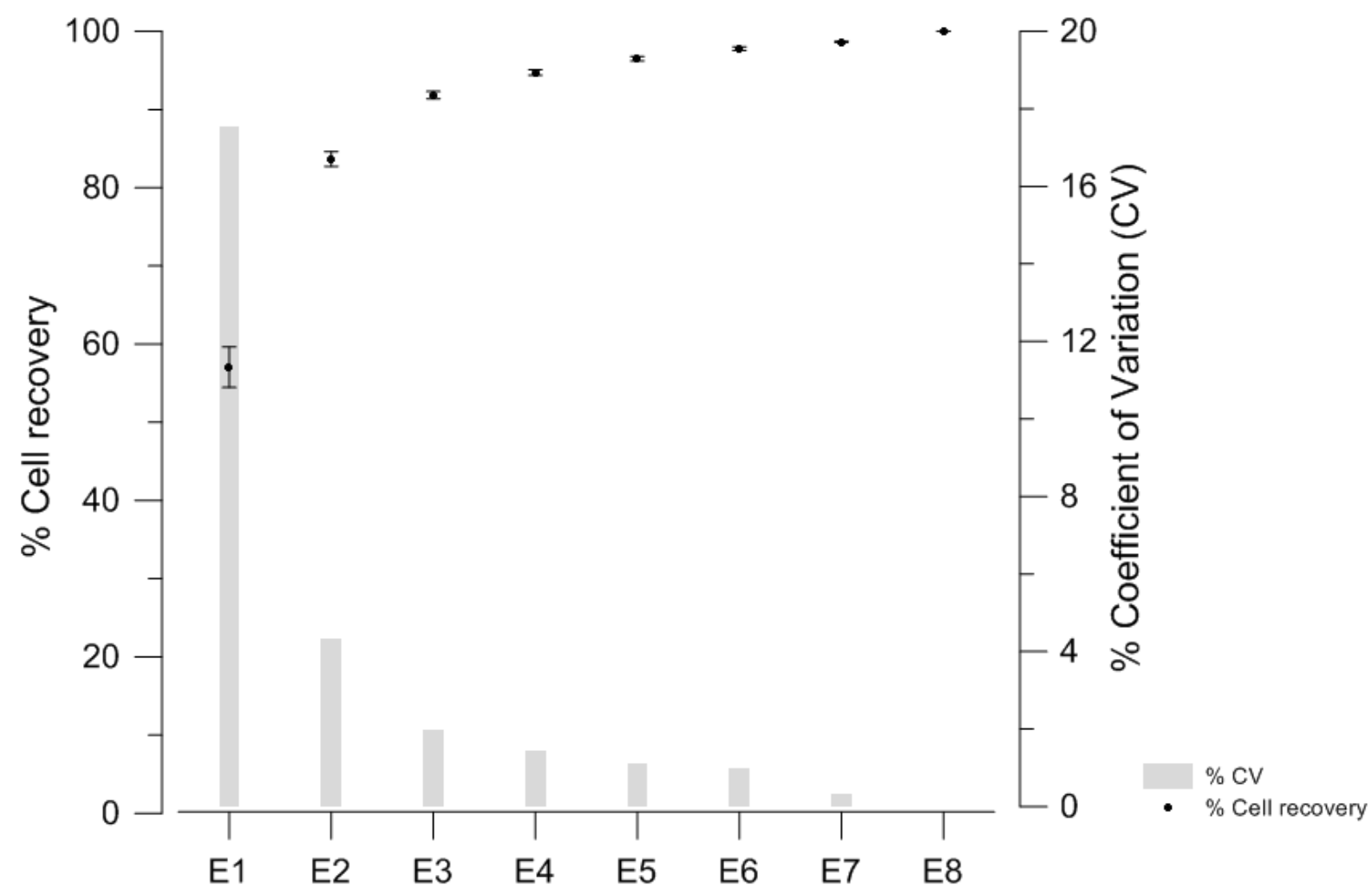

262 Fig. 2. Cumulative percentage of cell recovery using the final extraction protocol (extended to 263 eight extractions), counting by flow cytometry (FCM) and percentage coefficient of variation $264(\% \mathrm{CV})(\mathrm{n}=15)$. Black dots represent cell recovery efficiency with standard errors and grey 265 bars represent \% CV, E = extraction number.

266

single column fitting image 
3.4 Microscopy versus flow cytometry

Fifty five muddy samples were tested and highly significant correlations were found 269 between EFM and FCM counts (Fig. 3; t-test: $\mathrm{R}^{2}=0.615$, df $=53$, p-value $<0.001$ ). Moreover, 270 cell abundance estimated by FCM was always higher than cell abundance counted by EFM, 271 by a factor of 1.81 . Thus, EFM and FCM results followed the same trends but FCM always 272 allowed detecting more cells than EFM. We prove by this way that the traditional method by 273 EFM need to be re-evaluated and that FCM can be a better method to assess the heterotrophic 274 prokaryotic abundance. 


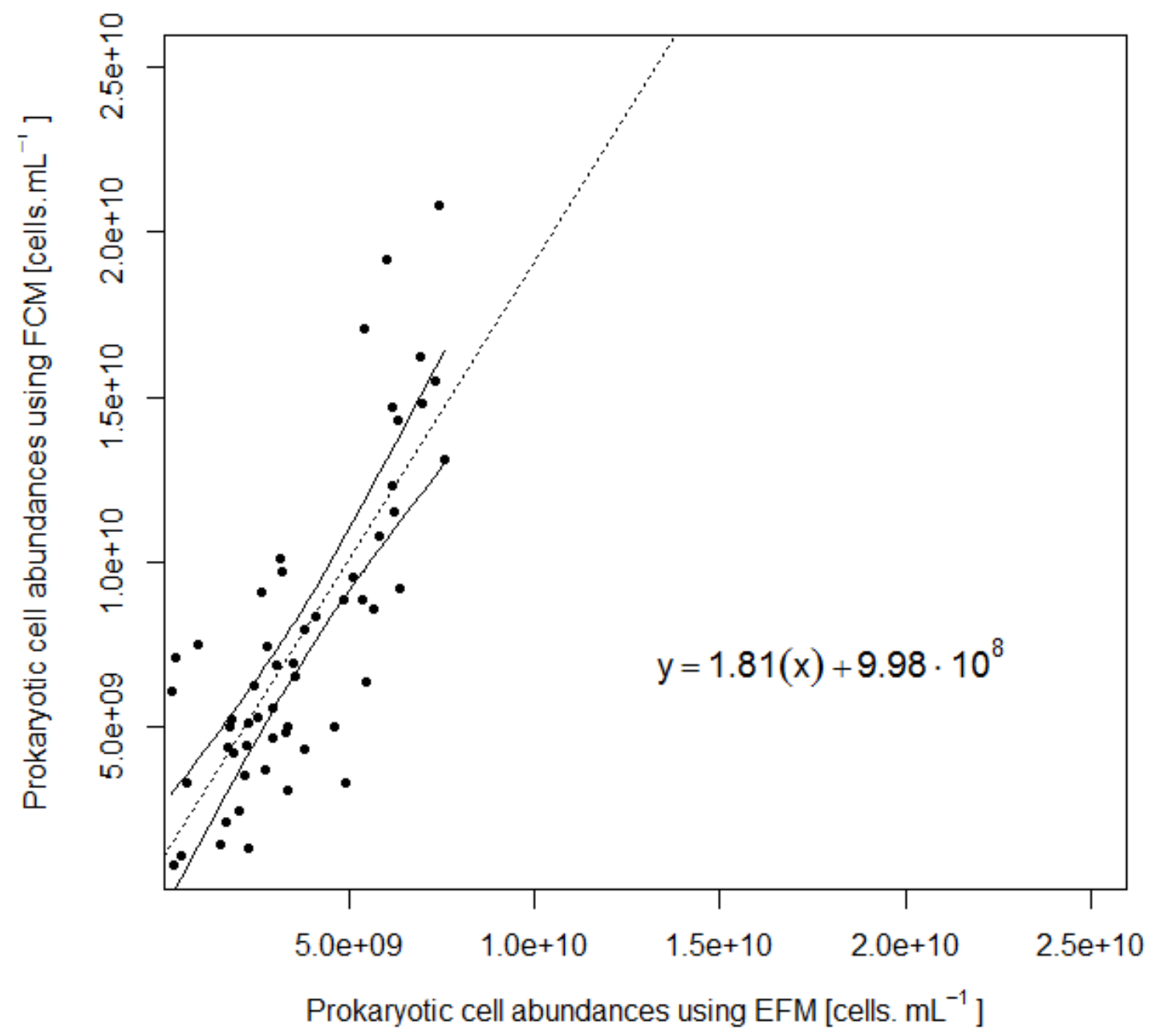

276 Fig. 3. Linear regression between prokaryotic cell abundance determined by flow cytometry 277 (FCM) and observed by epifluorescence microscopy (EFM). Samples come from the Moëze 278 mudflat at different depths and sampling seasons $(n=55)$, dot line corresponding to the 279 regression line and envelopes represent $95 \%$ confidence intervals. Significant adjusted R280 squared: 0.615 (t-test: F-stat : 87.3, df =53, p-value <0.001).

single column fitting image 


\subsection{Which type of storage?}

The influence of storage conditions on prokaryotic cells was studied. After the first 284 month of storage, a loss of $24.46 \% \pm 4.5$ SE of cells was observed under the two storage 285 conditions $\left(-80^{\circ} \mathrm{C}\right.$ and $\left.+4^{\circ} \mathrm{C}\right)$. After that, prokaryotic abundances remained stable until 6 286 months (-4\%; Fig. 4). High standard error bars on Fig. 4 were due to the differences in 287 prokaryotic abundances between sample depths, but the results brought out that prokaryotic 288 abundances in samples stored at $-80^{\circ} \mathrm{C}$ tend to be higher than in those conserved at $+4^{\circ} \mathrm{C}$. A 289 significant difference was detected between T0 and 12 weeks after sampling (Tukey HSD; $p$ 290 value $<0.05)$, nevertheless, neither the temperature of storage nor the interaction with time 291 influenced the abundance of prokaryotes counted (2-way ANOVA, $p$-value $>0.05$ ). After 3 292 months, the abundances measured with the final protocol were more variable. The 293 recommended protocol is to store fixed sediment samples at $-80^{\circ} \mathrm{C}$ (as for water samples, 294 (Marie et al., 1997)) and to analyse samples within 3 months after sampling. 


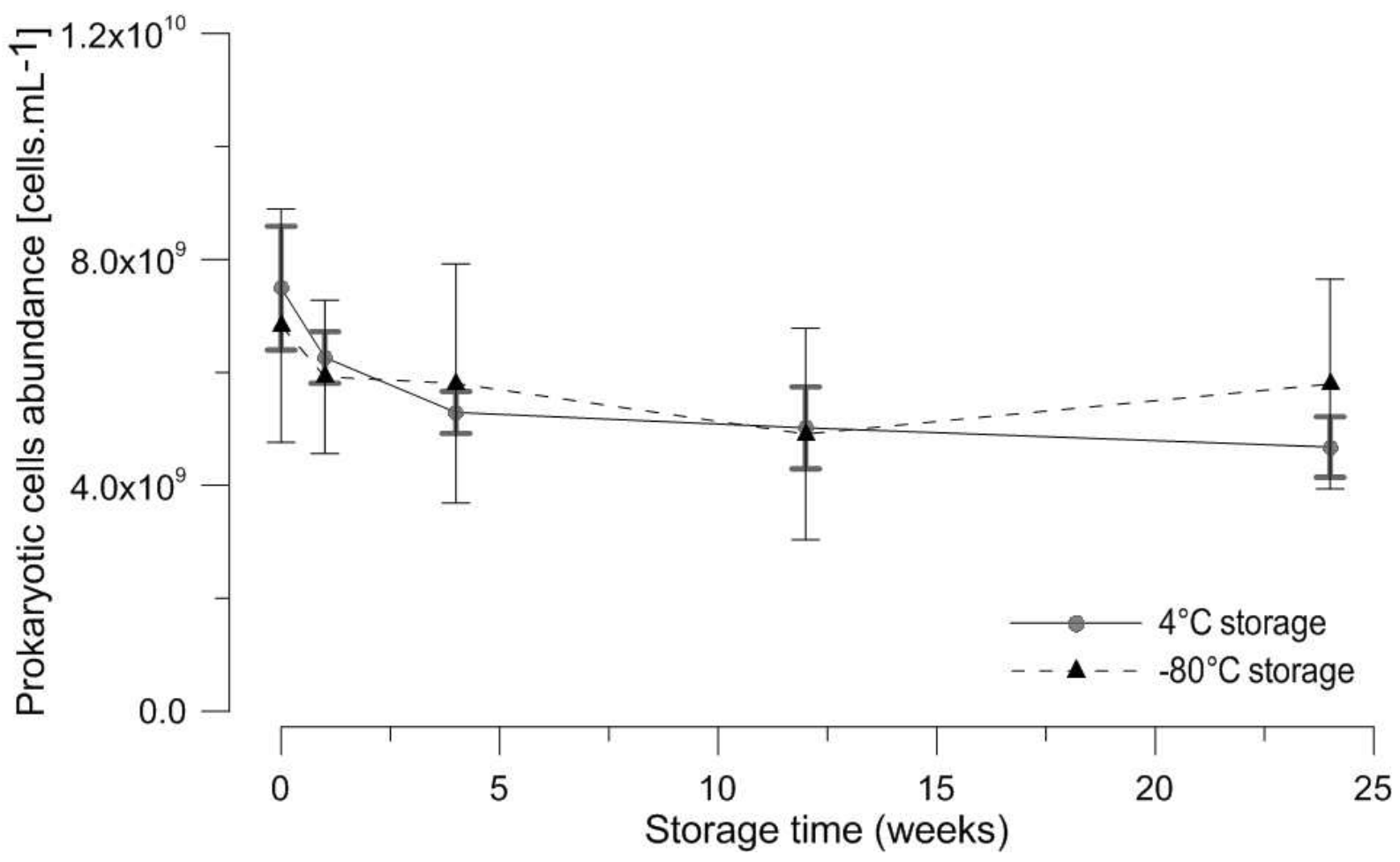

296 Fig. 4. Effects of storage temperature and time on heterotrophic prokaryotic cell abundance 297 obtained by flow cytometry (FCM) with the two-step protocol (mean values +/- standard 298 errors from five samples in duplicate are shown). 


\subsection{Final protocol}

All the assessments above resulted in a final protocol. This final protocol (Fig. 6)

301 detached and homogenized cells in sediment samples thanks to 2 successive extractions ( $\S$

3023.3 ) and allowed to count the prokaryotic cells using FCM.

1) Samples were prepared and extracted using: a dilution (1:1,000 to $1: 2,000)$ in a

304 detergent mix $(\S 3.1)$ [sodium pyrophosphate $(0.01 \mathrm{M})+$ Tween $80(0.1 \%)$ ] and a vortexing 305 step and $30 \mathrm{~min}$ of incubation at $+4^{\circ} \mathrm{C}$. After the vortexing step, a sonication separation for 30 $306 \mathrm{sec}(60 \mathrm{~W})$ in ice with a sonication probe $(3 \mathrm{~mm})$ was applied. Without any centrifugation step 307 (§ 3.2), an aliquot of the sample was stained with SYBRGreen I $(1: 10,000) 15$ min in the dark 308 and analyzed by flow cytometry (FCM).

309 2) the remaining part of the sample was centrifuged at low speed $(1 \mathrm{~min}$ at $1,000 \mathrm{~g}$ at $310+4^{\circ} \mathrm{C}$ ); the pellet was then resuspended in the detergent mix and step 1 was repeated once 311 more.

312 Using this two-step protocol, $83.67 \% \pm 3.63 \mathrm{SD}(\S 3.3)$ of total cells can be extracted from a 313 solid matrix and counted by SYBRGreenI-stained FCM. 
Counting method of benthic prokaryotes
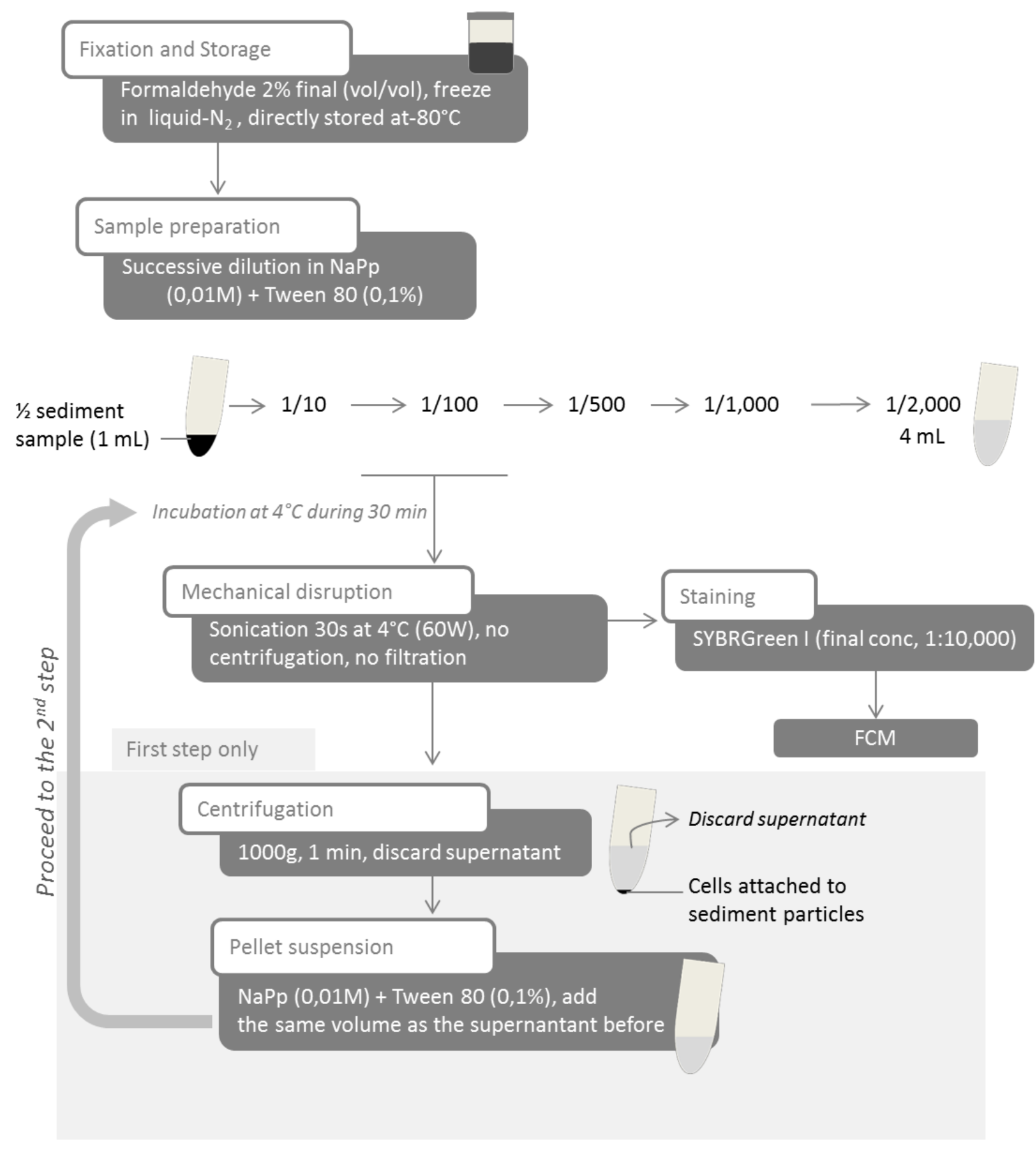

315 Fig. 5. Final protocol of the improved two-step separation method. FCM = Flow Cytometry ;

$316 \mathrm{NaPp}=$ sodium pyrophosphate. 


\subsection{Application on different types of sample}

To validate the protocol, the method for FCM analysis was applied to sandy, sandy-

320 mud and muddy sediments from different locations with different values of sand contents

321 (from 0 to $90 \%$ ) following a range of silt/sand content. For each sample, the cell recovery 322 percentages of the first step extraction were high, by mean $61 \%$ ranging from $55 \%$ to $68 \%$ 323 (Fig. 6; Supplementary Information Table 2.). The cell recovery efficiencies of these samples 324 were in the same range and there were no significant effects of the sand content on the cell 325 recovery of the first extraction (Kruskal-Wallis test; $\chi^{2}=5 ; \mathrm{df}=5 ; p$-value $=0.4159$ ). These 326 results showed that our developed method is efficient for sandy, sandy-mud and muddy 327 sediments tested whatever the location and sand content or composition. 


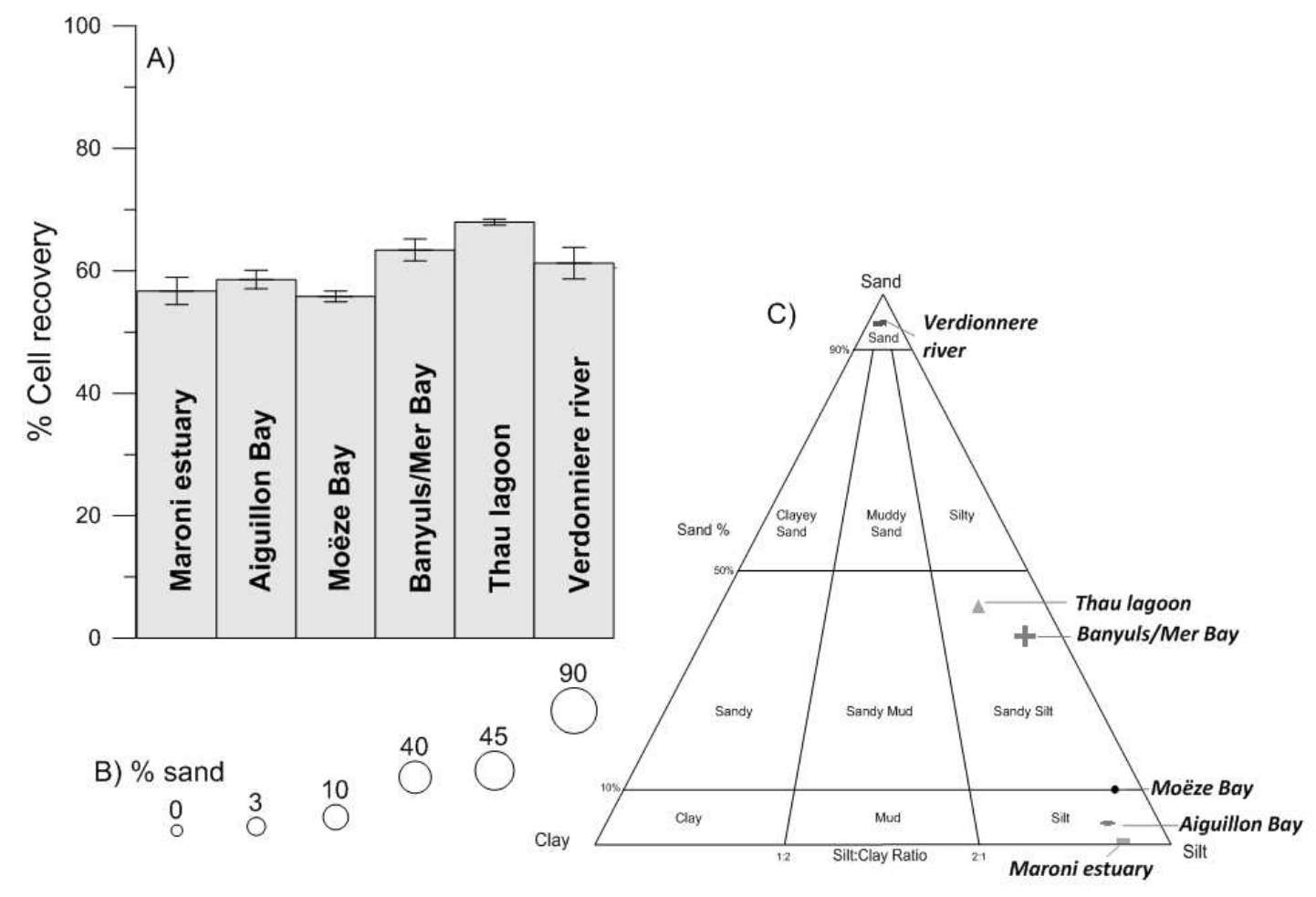

330 Fig. 6. A) Percentage of cells extracted after the first step by applying our two-step extraction

331 method followed by FCM heterotrophic prokaryotic enumeration on sandy and muddy

332 sediment samples from diverse locations with a range of sand percentages. B) Sand

333 percentages for each sample. C) Sand/Silt/Clay diagram for each sample.

2-column fitting image 


\section{Discussion and Conclusions}

Flow cytometry (FCM) is now widely used for water column analysis in order to estimate autotrophic diversity and abundance, and to enumerate heterotrophic prokaryotes (Legendre et al., 2001). For sediment analysis, technical advances have been made but not well optimized to get an efficient and rapid method for FCM. The main difficulty remains the necessary step of cell preparation and separation from sediment which need to be adapted for each sediment type (Duhamel and Jacquet, 2006). Many authors have tried to find the best protocol for separating prokaryotic cells from a solid matrix. One particularly powerful way seems to be the density gradient application on various sediments (Aakra et al., 2000, Amalfitano and Fazi, 2008, Kallmeyer, et al., 2008, Lunau, et al., 2005, Morono, et al., 2013, Whiteley, et al., 2003), but these techniques are relatively time-consuming and expensive. The present study demonstrates a quick and efficient protocol for the enumeration of heterotrophic prokaryotes in coastal sediments.

Since EFM is the classic method of counting heterotrophic prokaryotic cells in sediment, our protocol of extraction followed by FCM analysis needs to be validated by EFM. We compared the cell abundance obtained by EFM (DAPI-stained cells) and FCM (SYBRGreenI-stained cells). The staining protocol used was different with the two methods (i.e. DAPI preferentially bind on $\mathrm{A}$ and $\mathrm{T}$ bases). The choice was to compare the traditional protocol (DAPI-stained cells) and the most used protocol in FCM (SYBRGreenI-stained cells). It is known that the two dyes may differ in terms of binding and affinity on DNA and RNA (simple and double-stranded) (Marie, et al., 1997, Troussellier et al., 1999) and thus can produce different results. Nevertheless, DAPI-stained samples (sorted and non-sorted sediment samples) were counted using FCM equipped with a violet laser $(407 \mathrm{~nm})$. Cytograms were weakly exploitable because DAPI fluorescence yield was not optimal at 407 $\mathrm{nm}$ (optimal wave length $=375 \mathrm{~nm}$ ) resulting in a low signal resolution and thus high 
fluorescence background of DAPI (data not shown). Moreover, observations of SYBRGreenIstained cells under EFM were not satisfactory.

Finally, FCM appeared to be a consistent method to count benthic prokaryotes as it allows the detection of 1.81 times more cells than EFM with a significant correlation. The explanation could be that EFM is human-dependent and biased by the cell location of the filter (can be hidden by sediment particles). FCM allows assessment of particle count as well as multi-parameters analysis for each cell (Bouvier et al., 2001, Porter et al., 1997). The use of FCM increases counting efficiency as compared to the classic EFM method, and the estimation of prokaryotic abundance is consistent.

Liquid $\mathrm{N}_{2}$ storage is the most widely used method of conserving prokaryotic cells in water samples for FCM analysis (Vaulot et al., 1989), but in the case of benthic prokaryotic cells, samples are usually directly counted or stored at $+4^{\circ} \mathrm{C}$ before EFM counting (Ellery and Schleyer, 1984, Epstein and Rossel, 1995). We then propose to fix the sediment samples with $2 \%$ formaldehyde solution and after liquid- $\mathrm{N}_{2}$ fixation, store them immediately at $-80^{\circ} \mathrm{C}$ and then count within 3 months after sampling.

Many authors had proposed protocols for FCM analysis including a centrifugation step and/or a filtration through $5 \mu \mathrm{m}$ because it can limit detritus clogging in the cytometer nozzle (Duhamel and Jacquet, 2006). The present study brings out that without centrifugation, the sediment particles can settle in the tube and did not accumulate in the flow cytometer nozzle, and FCM analysis was possible. To develop a rapid and easy protocol, we proposed to analyse samples without the centrifugation step and then to centrifuge samples afterward to proceed to the second extraction (on the pellet). 
Taking into considerations all these features, the development of the protocol focused

383 on a method of cell separation to define a simple, inexpensive, and rapid method to enumerate prokaryotes in sediment.

Kallmeyer, et al. (2008) extracted between 65 and 100\% of prokaryotic cells in deep subsurface sediments by applying a bilayer density gradient. In soil, Barra Caracciolo, et al. (2005) also used a bilayer gradient density as well, and were able to extract up to $77 \%$ of total prokaryotic cells. More recently, Morono, et al. (2013) applied a multilayer density gradient on samples from marine subsurface and obtained from 50 to $80 \%$ cell recovery. Lunau, et al. (2005) worked on muddy and sandy sediments and opted for a low-speed centrifugation method combined with a methanol purification step; by an EFM analysis, they achieved 54 to $114 \%$ cell recovery. Even if the cell recovery had been found to be variable among the physico-chemical parameters of a solid matrix (Maron, et al., 2006), we confirmed that our method is consistent and quicker, and can be applied to different kind of benthic samples. It allows the extraction of a large quantity of prokaryotic cells (between $10^{8}$ and $10^{10}$ cells.mL $\mathrm{mL}^{-1}$ ) and the possibility of determining prokaryotic abundances ( $83.67 \%$ mean cell recovery).

Nevertheless, it is clear that some optimization details must be done for each type of samples. We suggest staining cells with more concentrated SYBRGreen I (1:5,000 final concentration) if the prokaryotic population is not easily distinguishable from background noise due to organic and mineral matter. Obviously, during the FCM analysis, threshold and fluorescent parameters must be adapted to population characteristics as well as the dilution of the sample.

Our two-step extraction method is simple to apply, as it allows the estimation of heterotrophic prokaryotic abundance of 30 sediment samples within 4 hours. This method was applied successfully on different types of sediments (muddy and sandy, coastal marine sediments and freshwater sediment) and among the different types of sediments, our method 
407

408

was reproducible. Moreover, these applications showed that our method was suitable not only for coastal sediments but also for freshwater sediment (from the Verdonniere river streambed, France). Aiming at finding a method suitable for a large range of sediments samples, this study prove that our optimized method offers a better efficiency for different marine sediment types even for freshwater sediments. In soils, Williamson et al. (2013), showed a strong influence of clay content and recommended testing the influence of the extraction mixture prior to analyse the samples. Further analyses remain possible to establish whether our twostep protocol is efficient on clay-containing sediments.

This fast protocol using FCM is a methodological issue but is also crucial for ecological studies by allowing in the end a better understanding of marine benthic ecosystems. Finally, we can confirm that our protocol worked well for turbid water with high organic matter content in a study on prokaryotic community distribution among a salinity gradient in the Charente River (France). For this study, the dilution was adapted because prokaryotic abundance was between two and three orders of magnitude less than in the sediment samples.

In the future, we are convinced that our study can be useful for assessing activity, productivity or diversity analysis in sediments. Although, the abundance of prokaryotes is a central parameter to measure in all ecosystems, the next step to understand the functioning is evaluating the unknown genetic diversity (DeLong, 2009, Karl, 2007). And activity and productivity are powerful indices to characterize the community and are needed to show the key role of prokaryotic community in biogeochemical cycles. The combinations of our protocol and cell sorting (Wang et al., 2010) can be a great progress for sediment analysis. With cell sorting, it will be possible to sort cells according to their average side-anglescattered (SSC) light (Bernard et al., 2000) (proxy of size-class) for example and then do diverse analysis on different population of the prokaryotic community. 


\section{Acknowledgments}

This research was supported by a PhD grant from the Charente Maritime Department,

434 by the CPER 2006-2013 (Contrat Projet Etat Région) of Charente Maritime and by EC2CO

435 project (CAPABIOC, CNRS and INSU, 2013-2014). We are grateful to the cytometry and

436 imaging platform that provided organization and service in our lab. We also appreciate the

437 cytometry platform of Banyuls/Mer, which allows us to use cell-sorting cytometry. Authors

438 are grateful to E. Pante (LIENSs, La Rochelle) for his help. In our study, we analysed various

439 sediments and the authors would like to thank all those who provided the environmental

440 samples: P. Bocher (LIENSs, La Rochelle) in collaboration with D.S. Mizrahi (project

441 supporting by the US Fish and Wildlife Service and the Western Hemisphere Shorebird

442 Reserve Network, New Jersey Audubon Society), K. Guizien and S. Lucas (DynDiagHyd 443 project, EC2CO - LECOB, Banyuls/Mer), H. Montanie (Biofilms Project, FREDD - LIENSs,

444 La Rochelle) and F. Rossi (CHARM project, EC2CO - ECOSYM, Montpellier). Authors are 445 grateful to the anonymous reviewers for their thorough evaluations which help us to improve 446 the quality of manuscript. 
449

450

451

452

453

454

455

456

457

458

459

460

461

462

463

464

465

466

467

468

469

470

471

472

473

474

475

476

477

478

479

480

481

482

483

484

485

486

487

488

489

490

491

492

493

494

495

496

497

498

499

Aakra, A., Hesselsoe, M., Bakken, L.R., 2000. Surface Attachment of Ammonia-Oxidizing Bacteria in Soil. Microb Ecol. 39, 222-235.

Albright, L.J., McCrae, S.K., May, B.E., 1986. Attached and Free-Floating Bacterioplankton in Howe Sound, British Columbia, a Coastal Marine Fjord-Embayment. Appl Environ Microbiol. 51, 614-621. Amalfitano, S., Fazi, S., 2008. Recovery and quantification of bacterial cells associated with streambed sediments. J Microbiol Methods. 75, 237-243.

Amalfitano, S., Puddu, S.F., 2009. Flow cytometric analysis of benthic prokaryotes attached to sediment particles. J Microbiol Methods. 79, 246-249.

Azam, F., Malfatti, F., 2007. Microbial structuring of marine ecosystems. Nat Rev Micro. 5, 782-791.

Barra Caracciolo, A., Grenni, P., Cupo, C., Rossetti, S., 2005. In situ analysis of native microbial communities in complex samples with high particulate loads. FEMS Microbiol Lett. 253, 55-58.

Bernard, L., Courties, C., Servais, P., Troussellier, M., Petit, M., Lebaron, P., 2000. Relationships among Bacterial Cell Size, Productivity, and Genetic Diversity in Aquatic Environments using Cell Sorting and Flow Cytometry. Microb Ecol. 40, 148-158.

Bocher, P., Piersma, T., Dekinga, A., Kraan, C., Yates, M., Guyot, T., Folmer, E., Radenac, G., 2007. Site- and species-specific distribution patterns of molluscs at five intertidal soft-sediment areas in northwest Europe during a single winter. Mar Biol. 151, 577-594.

Bouvier, T., Troussellier, M., Anzil, A., Courties, C., Servais, P., 2001. Using light scatter signal to estimate bacterial biovolume by flow cytometry. Cytometry. 44, 188-194.

Ciobanu, M.-C., Burgaud, G., Dufresne, A., Breuker, A., Redou, V., Ben Maamar, S., Gaboyer, F., Vandenabeele-Trambouze, O., Lipp, J.S., Schippers, A., Vandenkoornhuyse, P., Barbier, G., Jebbar, M., Godfroy, A., Alain, K., 2014. Microorganisms persist at record depths in the subseafloor of the Canterbury Basin. ISME J.

Compton, T., Troost, T., van der Meer, J., Kraan, C., Honkoop, P., Rogers, D., Pearson, G., de Goeij, P., Bocher, P., Lavaleye, M., Leyrer, J., Yates, M., Dekinga, A., Piersma, T., 2008. Distributional overlap rather than habitat differentiation characterizes co-occurrence of bivalves in intertidal soft sediment systems. Mar Ecol Prog Ser. 373, 25-35.

Daley, R., 1979. Direct epifluorescence enumeration of native aquatic bacteria: uses, limitations, and comparative accuracy. In: J. W. Costerton, R. R. Colwell (Eds.), Native aquatic bacteria: enumeration, activity and ecology, Vol. 605, American Society for Testing Materials, pp. 29-45.

Danovaro, R., Dell'Anno, A., Trucco, A., Serresi, M., Vanucci, S., 2001. Determination of virus abundance in marine sediments. Appl Environ Microbiol. 67, 1384-1387.

Decho, A.W., 2000. Microbial biofilms in intertidal systems: an overview. Cont Shelf Res. 20, 1257 1273.

DeLeo, P.C., Baveye, P., 1996. Enumeration and biomass estimation of bacteria in aquifer microcosm studies by flow cytometry. Appl Environ Microbiol. 62, 4580-4586.

DeLong, E.F., 2009. The microbial ocean from genomes to biomes. Nature. 459, 200-206.

DeLong, E.F., Preston, C.M., Mincer, T., Rich, V., Hallam, S.J., Frigaard, N.U., Martinez, A., Sullivan, M.B., Edwards, R., Brito, B.R., Chisholm, S.W., Karl, D.M., 2006. Community genomics among stratified microbial assemblages in the ocean's interior. Science. 311, 496-503.

dos Santos Furtado, A.L., Casper, P., 2000. Different methods for extracting bacteria from freshwater sediment and a simple method to measure bacterial production in sediment samples. J Microbiol Methods. 41, 249-257.

Duhamel, S., Jacquet, S., 2006. Flow cytometric analysis of bacteria- and virus-like particles in lake sediments. J Microbiol Methods. 64, 316-332.

Ellery, W., Schleyer, M., 1984. Comparison of homogenization and ultrasonication as techniques in extracting attached sedimentary bacteria. Mar Ecol Prog Ser. 15, 247-250.

Epstein, S.S., Rossel, J., 1995. Enumeration of sandy sediment bacteria: search for optimal protocol. Mar Ecol Prog Ser. 117, 289-298.

Fazi, S., Amalfitano, S., Pernthaler, J., Puddu, A., 2005. Bacterial communities associated with benthic organic matter in headwater stream microhabitats. Environ Microbiol. 7, 1633-1640. 
Frischer, M.E., Danforth, J.M., Healy, M.A.N., Saunders, F.M., 2000. Whole-Cell versus Total RNA Extraction for Analysis of Microbial Community Structure with 16S rRNA-Targeted Oligonucleotide Probes in Salt Marsh Sediments. Appl Environ Microbiol. 66, 3037-3043.

Fuhrman, J.A., Griffith, J.F., Schwalbach, M.S., 2002. Prokaryotic and viral diversity patterns in marine plankton. Ecol Res. 17, 183-194.

Garet, M.-J., 1996. Transformation bactérienne de la matière organique dans les sédiments côtiers: relation entre les métabolismes respiratoires et les activités exoprotéolytiques bactériennes $\mathrm{Ph}$. $\mathrm{D}$. thesis Univ. of La Rochelle.

Gasol, J.M., 1993. Benthic flagellates and ciliates in fine freshwater sediments: calibration of a live counting procedure and estimation of their abundances. Microb Ecol. 25, 247-262.

Gasol, J.M., Del Giorgio, P.A., 2000. Using flow cytometry for counting natural planktonic bacteria and understanding the structure of planktonic bacterial communities. Sci Mar. 64, 197-224.

Gough, H.L., Stahl, D.A., 2003. Optimization of direct cell counting in sediment. J Microbiol Methods. 52, 39-46.

Ifremer, 2008. Réseau de suivi Lagunaire du Languedoc-Roussilon : Bilan des résultats 2008 Rapport RSL 08-9 pp. 50.

Ishii, K., Mussmann, M., MacGregor, B.J., Amann, R., 2004. An improved fluorescence in situ hybridization protocol for the identification of bacteria and archaea in marine sediments. FEMS Microbiol Ecol. 50, 203-213.

Jaspers, E., Overmann, J., 1997. Separation of bacterial cells by isoelectric focusing, a new method for analysis of complex microbial communities. Appl Environ Microbiol. 63, 3176-3181.

Jorgensen, B.B., Boetius, A., 2007. Feast and famine - microbial life in the deep-sea bed. Nat Rev Micro. 5, 770-781.

Kallmeyer, J., Smith, D.C., Spivack, A.J., D'Hondt, S., 2008. New cell extraction procedure applied to deep subsurface sediments. Limnol Oceanogr Methods. 6, 236-245.

Karl, D.M., 2007. Microbial oceanography: paradigms, processes and promise. Nat Rev Micro. 5, 759769.

Kuwae, T., Hosokawa, Y., 1999. Determination of Abundance and Biovolume of Bacteria in Sediments by Dual Staining with 4',6-Diamidino-2-Phenylindole and Acridine Orange: Relationship to Dispersion Treatment and Sediment Characteristics. Appl Environ Microbiol. 65, 3407-3412.

Lebaron, P., Troussellier, M., Got, P., 1994. Accucary of epifluorescence microscopy counts for direct estimates of bacterial numbers. J Microbiol Methods. 19, 89-94.

Legendre, L., Courties, C., Troussellier, M., 2001. Flow cytometry in oceanography 1989-1999: Environmental challenges and research trends. Cytometry. 44, 164-172.

Lei, Y., Stumm, K., Volkenborn, N., Wickham, S., Berninger, U.-G., 2010. Impact of Arenicola marina (Polychaeta) on the microbial assemblages and meiobenthos in a marine intertidal flat. Mar Biol. 157, 1271-1282.

Lindahl, V., Bakken, L.R., 1995. Evaluation of methods for extraction of bacteria from soil. FEMS Microbiol Ecol. 16, 135-142.

Llobet-Brossa, E., Rosselló-Mora, R., Amann, R., 1998. Microbial Community Composition of Wadden Sea Sediments as Revealed by Fluorescence In Situ Hybridization. Appl Environ Microbiol. 64, 2691-2696.

Lunau, M., Lemke, A., Walther, K., Martens-Habbena, W., Simon, M., 2005. An improved method for counting bacteria from sediments and turbid environments by epifluorescence microscopy. Environ Microbiol. 7, 961-968.

Marie, D., Partensky, F., Jacquet, S., Vaulot, D., 1997. Enumeration and cell cycle analysis of natural populations of marine picoplankton by flow cytometry using the nucleic acid stain SYBR Green I. Appl Environ Microbiol. 63, 186-193.

Marie, D., Partensky, F., Vaulot, D., Brussaard, C., 2001. Enumeration of Phytoplankton, Bacteria, and Viruses in Marine Samples, Curr Protoc Cytometry, John Wiley \& Sons, Inc.

Maron, P.-A., Schimann, H., Ranjard, L., Brothier, E., Domenach, A.-M., Lensi, R., Nazaret, S., 2006. Evaluation of quantitative and qualitative recovery of bacterial communities from different soil types by density gradient centrifugation. Eur J Soil Biol. 42, 65-73.

Montagna, P.A., 1982. Sampling Design and Enumeration Statistics for Bacteria Extracted from Marine Sediments. Appl Environ Microbiol. 43, 1366-1372. 
Morono, Y., Terada, T., Kallmeyer, J., Inagaki, F., 2013. An improved cell separation technique for marine subsurface sediments: Applications for high-throughput analysis using flow cytometry and cell sorting. Environ Microbiol. 15, 2841-2849.

Pascal, P.Y., Dupuy, C., Richard, P., Mallet, C., Arminot du Châtelet, E., Niquil, N., 2009. Seasonal variation in consumption of benthic bacteria by meio- and macrofauna in an intertidal mudflat. Limnol Oceanogr. 54, 1048-1059.

Porter, J., Deere, D., Hardman, M., Edwards, C., Pickup, R., 1997. Go with the flow - use of flow cytometry in environmental microbiology. FEMS Microbiol Ecol. 24, 93-101.

Porter, K., Feig, Y., 1980. The use of DAPI for identification and enumeration of bacteria and bluegreen algae. Limnol Oceanogr. 25, 943-948.

Riis, V., Lorbeer, H., Babel, W., 1998. Extraction of microorganisms from soil: evaluation of the efficiency by counting methods and activity measurements. Soil Biol Biochem. 30, 1573-1581.

Robertson, B.R., Button, D.K., 1989. Characterizing aquatic bacteria according to population, cell size, and apparent DNA content by flow cytometry. Cytometry. 10, 70-76.

Schneiderheinze, J., Armstrong, D., Schulte, G., Westenberg, D., 2000. High efficiency separation of microbial aggregates using capillary electrophoresis. FEMS Microbiol Lett. 189, 39-44.

Troussellier, M., Courties, C., Lebaron, P., Servais, P., 1999. Flow cytometric discrimination of bacterial populations in seawater based on SYTO 13 staining of nucleic acids. FEMS Microbiol Ecol. 29, 319-330.

Troussellier, M., Courties, C., Zettelmaier, S., 1995. Flow cytometric analysis of coastal lagoon bacterioplankton and picophytoplankton: fixation and storage effects. Estuar Coast Shelf Sci. 40, 621633.

Tso, S.F., Taghon, G.L., 1997. Enumeration of Protozoa and Bacteria in Muddy Sediment. Microb Ecol. 33, 144-148.

Vaulot, D., Courties, C., Partensky, F., 1989. A simple method to preserve oceanic phytoplankton for flow cytometric analyses. Cytometry. 10, 629-635.

Velji, M., Albright, L., 1986. Microscopic enumeration of attached marine bacteria of seawater, marine sediment, fecal matter, and kelp blade samples following pyrophosphate and ultrasound treatments. Can J Microbiol. 32, 121-126.

Wang, Y., Hammes, F., De Roy, K., Verstraete, W., Boon, N., 2010. Past, present and future applications of flow cytometry in aquatic microbiology. Trends in Biotechnology. 28, 416-424.

Whiteley, A.S., Griffiths, R.I., Bailey, M.J., 2003. Analysis of the microbial functional diversity within water-stressed soil communities by flow cytometric analysis and CTC+ cell sorting. J Microbiol Methods. 54, 257-267.

Whitman, W.B., Coleman, D.C., Wiebe, W.J., 1998. Prokaryotes: The unseen majority. Proc Natl Acad Sci USA. 95, 6578-6583.

Williamson, K., Corzo, K., Drissi, C., Buckingham, J., Thompson, C., Helton, R., 2013. Estimates of viral abundance in soils are strongly influenced by extraction and enumeration methods. Biol Fertil Soils, 1-13.

Yamamoto, N., Lopez, G., 1985. Bacterial abundance in relation to surface area and organic content of marine sediments. J Exp Mar Biol Ecol. 90, 209-220.

Yoon, W.B., Rosson, R.A., 1990. Improved Method of Enumeration of Attached Bacteria for Study of Fluctuation in the Abundance of Attached and Free-Living Bacteria in Response to Diel Variation in Seawater Turbidity. Appl Environ Microbiol. 56, 595-600. 
601

602

603

604

605

606

607

608

609

610

611

612

613

614

615

616

617

618

619

620

621

622

623

624

\section{Figures}

Fig. 1. Effects of the addition of Tween 80 to sodium pyrophosphate (NaPp) on prokaryotic cell abundance in sediment samples (FCM counts from SYBRGreen: $n=55$; EFM counts from DAPI: $n=36$ ). Values for all the samples tested are presented. Crosses represented samples extracted with Tween 80 and $\mathrm{NaPp}$, and circles represented samples extracted with NaPp alone.

Fig. 2. Cumulative percentage of cell recovery using the final extraction protocol (extended to eight extractions), counting by flow cytometry (FCM) and percentage coefficient of variation $(\% \mathrm{CV})(\mathrm{n}=15)$. Black dots represent cell recovery efficiency with standard errors and grey bars represent \% $\mathrm{CV}, \mathrm{E}=$ extraction number.

Fig. 3. Linear regression between prokaryotic cell abundance determined by flow cytometry (FCM) and observed by epifluorescence microscopy (EFM). Samples come from the Moëze mudflat at different depths and sampling seasons $(n=55)$, dot line corresponding to the regression line and envelopes represent $95 \%$ confidence intervals. Significant adjusted Rsquared: 0.615 (t-test: F-stat : 87.3, df =53, p-value <0.001).

Fig. 4. Effects of storage temperature and time on heterotrophic prokaryotic cell abundance obtained by flow cytometry (FCM) with the two-step protocol (mean values +/- standard errors from five samples in duplicate are shown).

Fig. 5. Final protocol of the improved two-step separation method. FCM = Flow Cytometry ; $\mathrm{NaPp}=$ sodium pyrophosphate.

Fig. 6. A) Percentage of cells extracted after the first step by applying our two-step extraction method followed by FCM heterotrophic prokaryotic enumeration on sandy and muddy sediment samples from diverse locations with a range of sand percentages. B) Sand percentages for each sample. C) Sand/Silt/Clay diagram for each sample. 


\section{Supplementary information}

626 Figure 1. Searching for the best protocol for enumeration of heterotrophic prokaryotes in 627 sediments

628

629 Table 1. Extraction, fixation and staining methods in literature

630 Table 2. Heterotrophic prokaryotes abundance (mean \pm SD) in different sediments and cell

631 recovery (\% with mean $\pm \mathrm{SD}$, min and $\max$ ) of the first extraction using the two-step 632 extraction protocol analysed by flow cytometry (FCM). 
The best detachment ?

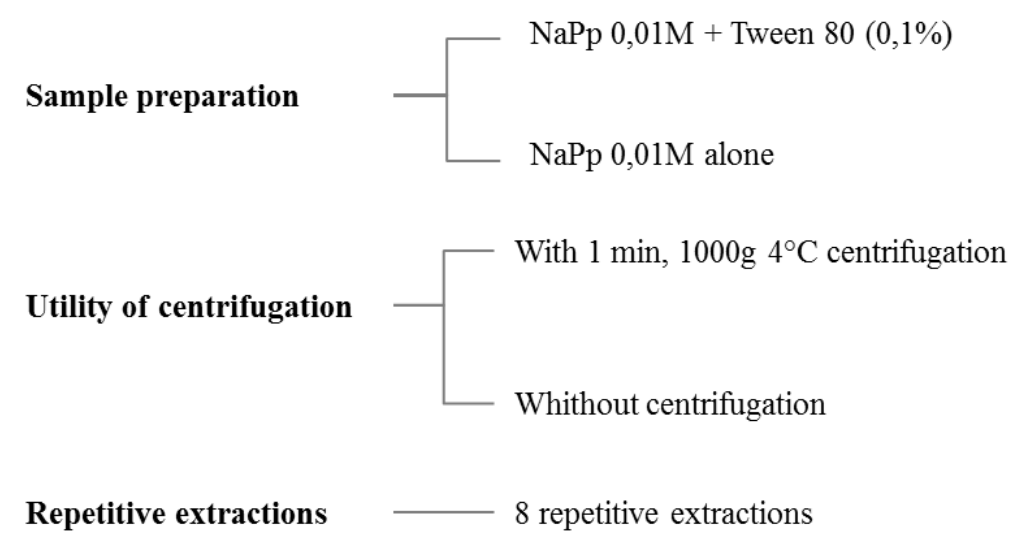

The best counting method?

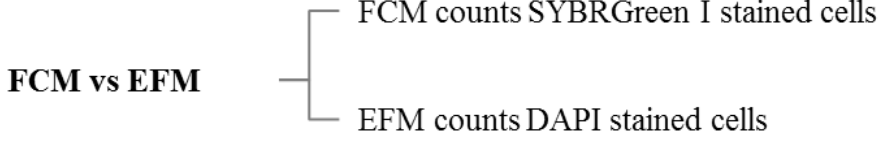

The best storage procedure ?

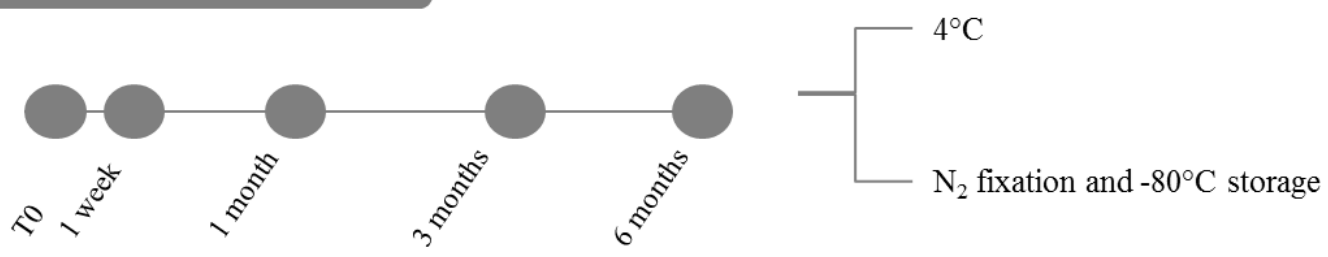

634 Figure 1. Searching for the best protocol for enumeration of heterotrophic prokaryotes in sediments 
635 Table 1. Extraction, fixation and staining methods in literature

\begin{tabular}{|c|c|c|c|c|c|c|c|c|c|}
\hline Sample type & $\begin{array}{l}\text { Fixation (final } \\
\text { concentration) }\end{array}$ & Chemical separation & physical disruption & Centrifugation & Additional step & $\begin{array}{l}\% \text { recovery } \\
\text { efficiency }\end{array}$ & Organisms & Staining (method) & References \\
\hline Turbid seawater & Glutaraldehyde (2\%) & $\begin{array}{l}\text { Sterile seawater }+0.001 \% \\
\text { Tween } 80\end{array}$ & $\begin{array}{l}\text { Sonication probe } 10 \mathrm{~W} 30 \mathrm{~s}+ \\
\text { blending } 5 \text { min at } 22000 \mathrm{rpm}\end{array}$ & - & & & Prokaryotes & DAPI (EFM) & Yoon and Rosson (1990) \\
\hline \multirow[t]{3}{*}{ Lake sediments } & Formaldehyde $(2 \%)$ & $\begin{array}{l}10 \mathrm{mM} \mathrm{NaPp}+10 \% \text { Tween } \\
80+\text { MilliQ Water }\end{array}$ & $\begin{array}{l}\text { Sonication } 3 \text { min stopped for } 30 \mathrm{~s} \\
\text { every minute+ shaking }\end{array}$ & $800 \mathrm{~g} 1$ min RT & 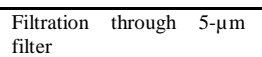 & & $\begin{array}{l}\begin{array}{l}\text { Prokaryotes, } \\
\text { Viruses }\end{array} \\
\end{array}$ & $\begin{array}{l}\text { SYBRGreen II } \quad \text { (EFM + } \\
\text { FCM) }\end{array}$ & Duhamel and Jacquet (2006) \\
\hline & Formalin $(3 \%) 4^{\circ} \mathrm{C}$ & & & $750 \mathrm{~g} 10 \min 4^{\circ} \mathrm{C}$ & & - & Prokaryotes & DAPI (EFM) & dos Santos Furtado and \\
\hline & $\begin{array}{l}\text { Paraformaldehyde }(4 \%) \\
4^{\circ} \mathrm{C}\end{array}$ & $\begin{array}{l}10 \mathrm{mM} \mathrm{NaPp}+120 \mathrm{mM} \mathrm{NaCl} \\
+10 \mathrm{mM} \mathrm{NaPO} 4\end{array}$ & Sonication bath 15 min & - & - & - & Prokaryotes & DAPI (EFM) & $\begin{array}{l}\text { Casper (2000) } \\
\text { Gough and Stahl (2003) }\end{array}$ \\
\hline Streambed sand & $\begin{array}{l}\text { Formaldehyde }(2 \%) \\
\end{array}$ & $0.1 \% \mathrm{NaPp}+0,5 \%$ Tween 20 & $\begin{array}{l}\text { Shaking } 30 \min , 720 \mathrm{rpm}+ \\
\text { sonication } 1 \mathrm{~min} 20 \mathrm{~W}\end{array}$ & $\begin{array}{l}14000 \mathrm{~g} 90 \mathrm{~min} \\
4^{\circ} \mathrm{C}\end{array}$ & $\mathrm{NGD}^{b}$ & $93 \%$ & Prokaryotes & $\begin{array}{lll}\begin{array}{l}\text { DAPI } \\
\text { (FCM) }\end{array} & \text { (EFM) } & \text { SYTO13 } \\
\end{array}$ & Amalfitano and Fazi (2008) \\
\hline \multicolumn{10}{|l|}{ Marine Sediments } \\
\hline $\begin{array}{l}\text { - Sands and muddy } \\
\text { sediments }\end{array}$ & Glutaraldehyde $(2 \%)$ & 10 mM P2O7 & 3 min sonication & $800 \mathrm{~g} 1 \mathrm{~min}$ RT & & $60 \%$ & Virus & SYBRGreen I & Danovaro et al. (2001) \\
\hline \multirow[t]{3}{*}{ - Sandy sediments } & Formaldehyde (4\%) & 1:1 PBS/Ethanol & Sonication min power $20 \mathrm{~s}$ & - & 3 washes before storage & - & Prokaryotes & DAPI (CARD-FISH) & Ishii et al. (2004) \\
\hline & Formaldehyde & $\begin{array}{l}\text { Sterile seawater }+0.0001 \% \\
\text { Tween80 }\end{array}$ & Sonication bath 200W $2.5 \mathrm{~min}$ & - & - & - & Prokaryotes & $\mathrm{AO}(\mathrm{EFM})$ & Ellery and Schleyer (1984) \\
\hline & Formaldehyde $(4 \%) 4^{\circ} \mathrm{C}$ & $\begin{array}{l}0.1 \mathrm{mM} \\
\text { Tween80 } \\
\text { NaPp }+0.0001 \%\end{array}$ & Sonication probe $3 \times 60 \mathrm{~s} 109 \mu \mathrm{m}$ & $500 \mathrm{~g} 5 \min \mathrm{RT}$ & 8 washes & & Prokaryotes & DAPI (EFM) & Epstein and Rossel (1995) \\
\hline \multirow[t]{2}{*}{$\begin{array}{l}\text { - Deep subsurface } \\
\text { sediments }\end{array}$} & $\begin{array}{l}\text { Formaldehyde }(2 \%) 6 \mathrm{~h} \\
4^{\circ} \mathrm{C}+\text { washing steps }\end{array}$ & $\mathrm{DT}^{a}{ }^{a}$ & $\begin{array}{l}\text { Shaking } 60 \mathrm{~min} 500 \mathrm{rpm} \\
\text { sonication probe } 20 \mathrm{~W} 1 \mathrm{~min}\end{array}$ & $\begin{array}{l}4500 \mathrm{~g} 15 \mathrm{~min} \text { and } \\
15000300 \mathrm{~min}\end{array}$ & MIGD $^{c}$ & & Prokaryotes & SYBRGreen I (FCM) & Morono, et al. (2013) \\
\hline & Formaldehyde $(2 \%) 4^{\circ} \mathrm{C}$ & $\mathrm{DT}^{a}$ & $\begin{array}{l}\text { Vortexing } 60 \mathrm{~min}+\text { sonication } \\
\text { probe } 5 \times 10 \mathrm{~s}\end{array}$ & $3000 \mathrm{~g} 10 \mathrm{~min} \mathrm{RT}$ & $\begin{array}{l}\text { Carbohydrates dissolution } \\
+2 \mathrm{NGD}^{b} \text { steps }\end{array}$ & 65 to $100 \%$ & Prokaryotes & $\begin{array}{l}\text { SYBRGreen } \mathrm{I}+0.1 \% p \text { - } \\
\text { phenylenediamine }(\mathrm{EFM})\end{array}$ & Kallmeyer, et al. (2008) \\
\hline - Muddy sediments & - & $10 \%$ methanol & $\begin{array}{l}\text { Sonication bath } 320 \mathrm{~W} 15 \mathrm{~min} \\
35^{\circ} \mathrm{C}\end{array}$ & $190 \mathrm{~g} \operatorname{lmin}$ & - & $54-114 \%$ & Prokaryotes & SYBRGreen I (EFM) & Lunau, et al. (2005) \\
\hline \multirow[t]{2}{*}{ Soil } & no fixation & $0.2 \% \mathrm{NaP} 2 \mathrm{O} 7$ & $0.5 \mathrm{~h}$ intensive shaking & $600 \mathrm{~g} 5 \mathrm{~min}$ RT & & $45 \%$ & Bacteria, fungi & DAPI (EFM) & Riis et al. (1998) \\
\hline & Formaldehyde (2\%) & $\mathrm{PBS}+\mathrm{Tw} w e n 20+\mathrm{NaPp}$ & $\begin{array}{l}\text { Shaking } 15 \text { min at } 400 \mathrm{rpm} \\
\text { (orbital shaker) }\end{array}$ & $\begin{array}{l}14000 \mathrm{~g} 90 \mathrm{~min} \\
4^{\circ} \mathrm{C}\end{array}$ & $\begin{array}{l}\mathrm{NGD}^{b}+\text { filtration through } \\
0,2-\mu \mathrm{m} \text { filter }\end{array}$ & $77 \%$ & Prokaryotes & DAPI (FISH) & Barra Caracciolo, et al. (2005) \\
\hline \multirow[t]{2}{*}{ Aquifere } & Formaldehyde $(0,5 \%)$ & $0.1 \% \mathrm{NaP2O}$ & $\begin{array}{l}\text { Shaking } 60 \mathrm{~min} \text { at } 155 \mathrm{rpm} \text { at } \\
25^{\circ} \mathrm{C}\end{array}$ & & & & & Propidium iodide (EFM) & DeLeo and Baveye (1996) \\
\hline & Formaldehyde ( $2 \%)$ & PBS+ $0,5 \%$ Tween 20 & $\begin{array}{l}\text { Shaking } 15 \mathrm{~min} \text { at } 400 \mathrm{rpm} \\
\text { (orbital shaker) }\end{array}$ & $\begin{array}{ll}14000 \mathrm{~g} & 90 \mathrm{~min} \\
4^{\circ} \mathrm{C} & \end{array}$ & $\begin{array}{l}\mathrm{NGD}^{b}+\text { filtration through } \\
0,2-\mu \mathrm{m} \text { filter }\end{array}$ & $78 \%$ & Prokaryotes & DAPI +(FISH) & Barra Caracciolo, et al. (2005) \\
\hline
\end{tabular}

${ }^{a} \mathrm{DI}-\mathrm{H} 2 \mathrm{O}+100 \mathrm{mM} \mathrm{EDTA}+100 \mathrm{mM} \mathrm{NaPp}+1 \%$ Tween $80+\mathrm{NaCl}+\mathrm{MeOH}$

${ }^{b}$ Nicodenz gradient density

'Multilayer Gradient density 
637 Table 2. Heterotrophic prokaryotic abundance (mean \pm SE) in different sediments tested and 638 cell recovery (\% with mean $\pm \mathrm{SE}$, min and max) of the first extraction using the two-step 639 extraction protocol analysed by flow cytometry (FCM).

\begin{tabular}{|c|c|c|c|c|c|c|c|c|c|}
\hline & Prokaryotes & bund & [cells.mL $\left.\mathrm{mL}^{-1}\right]$ & $\%$ sand & & Cell $\mathrm{r}$ & recover & $\mathrm{y}[\%]$ & \\
\hline & & & & & Mean & $(+/-S$ & & Min & Max \\
\hline Thau lagoon $(\mathrm{n}=48)$, France & $1.53 .10^{9}$ & $+/-$ & $4.46 .10^{7}$ & $45^{\mathrm{a}}$ & 67.98 & $+/-$ & 0.49 & 60.72 & 75.06 \\
\hline Intertidal Mudflat sediment & & & & & & & & & \\
\hline Moëze Bay $(n=45)$, France & $7.31 .10^{9}$ & $+/-$ & $2.92 .10^{8}$ & 10 & 55.81 & $+/-$ & 0.87 & 40.77 & 65.96 \\
\hline Aiguillon Bay $(n=42)$, France & $1.40 .10^{10}$ & $+/-$ & $4.34 .10^{8}$ & $3^{b}$ & 58.57 & $+/-$ & 1.51 & 32.31 & 69.35 \\
\hline Maroni estuary $(n=9)$, Surinam & $3.99 .10^{9}$ & $+/-$ & $3.37 .10^{8}$ & 0 & 56.70 & $+/-$ & 2.23 & 38.16 & 68.72 \\
\hline Sandy muddy coastal sediment & & & & & & & & & \\
\hline $\begin{array}{l}\text { Banyuls s/ mer Bay, France } \\
\text { Proteic enrichment }(n=32)\end{array}$ & $2.81 .10^{10}$ & $+/-$ & $5.52 .10^{8}$ & 40 & 62.81 & $+/-$ & 1.29 & 38.14 & 72.90 \\
\hline $\begin{array}{l}\text { Banyuls s/ mer Bay, France } \\
\text { Glucidic enrichment }(n=60)\end{array}$ & $1.46 .10^{10}$ & $+/-$ & $3.47 .10^{8}$ & 40 & 64.03 & $+/-$ & 0.88 & 41.56 & 72.75 \\
\hline Sandy streambed sediment & & & & & & & & & \\
\hline Verdonniere River $(n=11)$ & $6.75 .10^{9}$ & $+/-$ & $1.41 .10^{9}$ & 90 & 61.25 & $+/-$ & 2.57 & 48.86 & 81.59 \\
\hline & & & & TOT & $\underline{61.02}$ & $+/-$ & $\underline{1.40}$ & & \\
\hline
\end{tabular}

